\title{
Artur Grabowski*
}

Uniwersytet Ekonomiczny w Katowicach

\section{ORDOLIBERALNA KATEGORIA WOLNOŚCI NA PRZYKŁADZIE WALTERA EUCKENA I WILHELMA RÖPKEGO}

\section{STRESZCZENIE}

W artykule podjęto problem jednej z kluczowych kategorii ekonomicznych, jaką jest wolność, bardzo istotną dla ordoliberalizmu. Wynikało to z założeń doktryny ordoliberalnej, która na fundamencie ładu prawno-instytucjonalnego opartego na wolności, stworzyła porządek, z którego wyłoniła się (społeczna) gospodarka rynkowa. Dominowała w nim wolność, ale także konkurencja i prywatna własność. Dla Waltera Euckena i Wilhelma Röpkego - czołowych przedstawicieli ordoliberalizmu - to wolność stanowiła podstawową zasadę porządku rynkowego i zapewnienie jej każdemu obywatelowi było elementarnym obowiązkiem państwa prawa.

Słowa kluczowe: gospodarka rynkowa, konkurencja, ordoliberalizm, wolność

\section{Wprowadzenie}

Ordoliberalizm to kierunek ekonomiczny, który miał zróżnicowane oblicze, mimo tego nie trudno wskazać na pryncypia ordoliberalne. Wśród nich znajdowała się m.in. prywatna własność środków produkcji i kapitału, a jedynie akceptowalnym

\footnotetext{
*E-mail. artur.grabowski@ue.katowice.pl
} 
systemem gospodarczym była gospodarka rynkowa oparta właśnie na wolności i porządku prawnym.

Celem niniejszego artykułu jest przedstawienie znaczenia kategorii wolności w myśli ordoliberalnej na przykładzie twórczości dwóch wiodących przedstawicieli tego kierunku, czyli Waltera Euckena i Wilhelma Röpkego. Wybór wynikał z faktu, iż obaj autorzy byli ważnymi twórcami doktryny ordoliberalnej, a ich publikacje przynależą do klasycznych w niemieckiej myśli ekonomicznej. Przeprowadzono kwerendę literatury niemieckojęzycznej i na podstawie krytycznej analizy źródeł (zwartych i artykułów) zaprezentowano kluczowe myśli obu autorów związane z kategorią wolności.

\section{Geneza ordoliberalizmu}

Ordoliberalizm stanowił odpowiedź na dominującą w ówczesnych Niemczech szkołę historyczną, w której dominowało podejście narodowe oraz zasada interwencjonizmu państwowego. Tymczasem ordoliberalizm stanowił trzecią drogę pomiędzy kapitalizmem i komunizmem. Jego początki sięgają 1932 roku, kiedy powołano do życia Wspólnotę Badawczo-Naukową Prawników i Ekonomistów. Wśród jej założycieli znajdował się m.in. Walter Eucken, a Wilhelm Röpke był jej czołowym przedstawicielem. To właśnie Röpke stworzył podstawy socjologiczno-filozoficzne doktryny ordoliberalnej, a za powstanie fundamentów ekonomicznych odpowiadał Eucken. Zamiarem tego ostatniego było stworzenie takiego porządku ekonomicznego, w którym zachowana byłaby godność osobista jednostki i byłby to jednocześnie porządek ekonomicznie funkcjonalny. W tym porządku kluczowym było uznanie za podstawowe wolnościowych praw człowieka. Bliskość duchowa Euckena ze spuścizną Immanuela Kanta i Gottfrieda Wilhelma Leibnitza oznaczała w praktyce, że stworzony przez niego ordoliberalny system polityczno-gospodarczy był zbudowany na filarach, wśród których wyróżniała się przede wszystkim wolność. Tymczasem idea społeczna Röpkego obejmowała jeszcze konieczność istnienia duchowości, humanizmu i moralności w ładzie gospodarczym. Stąd też pisał o przymiotach ducha (godność, piękno, poezja, wdzięk, rycerskość, miłość, przyjaźń), które nie podlegają wycenie przez rynek. To właśnie one doprowadziły człowieka m.in. do wolności i wielowymiarowości życia (Grabowski, 2013, s. 15-16). 
Wizja gospodarki rynkowej według ordoliberałów obejmowała powstanie ładu prawnego ustanowionego przez państwo oraz zawierała takie elementy podstawowe, jak wolność gospodarczą i funkcjonujący mechanizm rynkowy.

\section{Wolność w ujęciu Waltera Euckena}

W celu przedstawienia kluczowych poglądów W. Euckena na kwestię wolności dokonano analizy trzech jego publikacji: Nationalökonomie Wozu? („Czemu służy ekonomia polityczna?”, wydana w 1938 roku), Die Grundlagen der Nationalökonomie („Podstawy ekonomii politycznej”, wydana w 1939 roku) i Grundsätze der Wirtschaftspolitik (,Podstawy polityki gospodarczej”, wydane w 1952 roku).

Jako podstawowe założenie należy traktować słowa Euckena dotyczące państwa, którego zadania ograniczały się do udzielania wsparcia i dbania o istnienie porządku konkurencji przy braku ingerencji w procesy gospodarcze. Procesy te następowały jedynie w konsekwencji wolnych decyzji podejmowanych przez gospodarstwa domowe i przedsiębiorstwa (Eucken, 2005, s. 84-85). Państwo odpowiadało jedynie za powstanie formy, w jakich odbywała się konkurencja. Natomiast nie wolno było państwu - według Euckena - planować i sterować procesami gospodarczymi (Eucken, 2001, s. 77). Było to konkretne przeciwstawienie się systemowi nakazowo-rozdzielczemu i gospodarce scentralizowanej, która została uznana przez Euckena za szkodliwą zarówno dla wolności jednostek, jak i poszczególnych podmiotów gospodarczych (Eucken, 2005, s. 70, 71, 80). Krytyka Euckena w stosunku do ustroju gospodarczego opartego na scentralizowanym aparacie sterującym procesami gospodarczymi wynikała z tego, że kategoria bezpieczeństwa była przeciwstawiona wolności. Wybór jednej z nich oznaczał rezygnację z drugiej. Było to nie do przyjęcia przez Euckena, ponieważ w jego opinii bezpieczeństwo bez wolności nie mogło zaistnieć. Oprócz tego pomiędzy państwem prawa a gospodarką centralnie planowaną występowała jawna sprzeczność: kontrola procesów gospodarczych w ramach systemu nakazowo-rozdzielczego oznaczała unieważnienie istnienia państwa prawa. Natomiast z kolei bez urzeczywistnienia państwa prawa, wolność jednostki nie była możliwa w praktyce (Eucken, 1990, s. 125, 126, 130).

W ordoliberalnym porządku prawnym każdy obywatel posiadał zapewnioną wolność oraz korzystał z katalogu praw podstawowych. Do nich należały m.in. wolność wypowiedzi, swoboda wyboru miejsca zamieszkania i zapewnienie prywatnej 
własności. Ponadto każdy człowiek posiadał ochronę w ramach istniejącego państwa prawa przed atakami ze strony innych obywateli. Wolność ekonomiczna według Euckena miała podwójne znaczenie dla polityków gospodarczych. Z jednej strony była podstawą godnego życia osobistego jednostek, a z drugiej umożliwiała jednostkom urzeczywistnienie kreatywnych planów, które wynikały z określonych praw ekonomicznych. Jednocześnie mogło się okazać w praktyce, iż przyznanie wolności rodziło zagrożenia dla samej wolności, czego dowodem była koncentracja siły ekonomicznej, która wzbudziła nadzwyczajną energię, jednakże mogła ona również przyczynić się do niszczenia wolności. Stąd też - zauważył Eucken - wolny i naturalny porządek nie powstał od tak po prostu, bo politycy gospodarczy pozwolili na jego rozwój, lecz wymagał odpowiedniego nakierowania. Dlatego znakami rozpoznawczymi ordoliberalnej polityki gospodarczej było stworzenie reguł gry rynkowej, warunków ramowych i form, w jakich odbywały się procesy gospodarcze. Natomiast same procesy gospodarcze, do których dochodziło każdego dnia, były wyłączną sprawą jednostek (Eucken, 1990, s. 48-50, 53, 54).

Kwestia wolności była przede wszystkim ściśle połączona z regulacjami dotyczącymi procesów gospodarczych i porządkiem gospodarczym. Dla Euckena nie było antynomii pomiędzy wolnością i porządkiem. Do idei porządku przynależała wolność. Wolność miała granice, które wyznaczały zagrożenia dla tego porządku (ładu). Pomiędzy wolnością a porządkiem (ładem) istniała wzajemna relacja. Z wolności powstawały spontanicznie formy porządku (ładu), o tyle, o ile znajdowały swe uzasadnienie w zgodzie z konkurencją. Pomiędzy „konstytucją państwową” a „konstytucją gospodarczą” i porządkiem społecznym istniała wzajemna współzależność. „Konstytucja gospodarcza” była dla Euckena całościową decyzją dotyczącą ładu gospodarczego w danym państwie. Porządek konkurencji posiadał zalety, wśród których znajdował się stan równowagi pomiędzy wolnością a porządkiem (Eucken, 1950, s. 52, 53, 81, 82).Do powstania ustroju gospodarczego opartego na konkurencji potrzebne było: a) zbudowanie przez państwo ram prawnych, b) istnienie mechanizmu popytu i podaży, c) istnienie prywatnej własności środków produkcji. Zasady konkurencyjnego ładu gospodarczego Euckena zawierały zasady konstytuujące i regulujące. Do zasad konstytuujących należały: stabilna wartość pieniądza, otwarte rynki, prywatna własność środków produkcji, swoboda zawierania umów, odpowiedzialność materialna za wyniki działalności gospodarczej i stałość polityki gospodarczej. Zasady konstytuujące były jednocześnie zasadami „konstytu- 
cji gospodarczej". Tymczasem opracowane przez Euckena zasady regulujące miały wpłynąć na zachowanie funkcjonalności ustroju gospodarczego opartego na konkurencji. Tymi zasadami były narzędzia polityki gospodarczej, które wykazywały zgodność z mechanizmem funkcjonowania cen rynkowych. Poza tym obejmowały dbanie o istnienie ładu konkurencyjnego, który obowiązywał nawet w przypadku występowania zachowań monopolistycznych i oligopolistycznych. W takiej sytuacji umiejętnie prowadzona polityka gospodarcza miała przyczynić się do wytworzenia warunków jak najbardziej zbliżonych do konkurencji. Następnym bardzo ważnym elementem była walka przeciwko ograniczaniu liczby monopoli, ale także prowadzenie działań przez urząd antymonopolowy, które będą wpływały na zapobieganie powstawania nowych. Kolejną istotną zasadą był podział dochodów przy jednoczesnym spełnieniu dwóch warunków: a) istnienia konkurencji, b) cen odzwierciedlających wskaźnik rzadkości dóbr i zasobów. Nieuwzględnienie przez przedsiębiorstwa zewnętrznych efektów produkcji spowodowało konieczność ingerencji w przebieg procesów gospodarowania przez narzędzia polityki gospodarczej. Zasady konstytuujące i regulujące należy rozpatrywać łącznie. Poszczególne zasady uzupełniają się nawzajem, są komplementarne. Polityka gospodarcza prowadzona konsekwentnie i zgodnie z oboma rodzajami zasad (konstytuującymi i regulującymi), doprowadzić mogła do sytuacji, iż zostanie zbudowany funkcjonalny porządek konkurencji (Eucken, 1990, s. 254-304).

Umieszczenie przez Waltera Euckena wśród zasad konstytuujących prywatnej własności środków produkcji i swobody zawierania umów niosło ze sobą pewne konsekwencje. Wskazywało na istnienie pozytywnej korelacji pomiędzy wolnością jednostki a istnieniem rynkowego ładu gospodarczego. Prywatna własność środków produkcji była, według Euckena, warunkiem porządku konkurencji. A ten z kolei był konieczny, aby prywatna własność środków produkcji nie prowadziła do braków gospodarczych i społecznych. Prywatna własność środków produkcji wymagała niezbędnej „kontroli” ze strony konkurencji. Tymczasem własność prywatna była przesłanką do zapewnienia prywatnej sfery wolności. Nowoczesne gospodarki, w których istniał porządek konkurencji, stworzyły warunki do trwałej obecności własności prywatnej. To właśnie prywatna własność była warunkiem wstępnym dla wolnego porządku państwowo-społecznego. Praktycznym przejawem egzystowania konkurencji była swoboda (wolność) zawierania umów. Bez niej nie było możliwe istnienie konkurencji i realizacja indywidualnych planów gospodarstw domowych 
oraz przedsiębiorstw. Jednocześnie swoboda zawierania umów wymaga ustalenia pewnych granic, wynikających $\mathrm{z}$ ładu konkurencyjnego, i nie może na przykład przyczyniać się do tworzenia monopoli (Eucken, 1990, s. 249, 275, 278).

Eucken sformułował wolnościowy program, który miał służyć rozwiązaniu ekonomiczno-technicznych problemów ładu konkurencyjnego w odniesieniu do całokształtu życia społecznego. Jednocześnie do jego urzeczywistnienia było potrzebne istnienie wśród ludzi woli porządku wolnościowego. Dlatego też zachęcał do odwagi i mobilizowaniu sił ludzkich do codziennej pracy nad budową porządku wolnościowego (Eucken, 1990, s. 370-371).

\section{Wolność w ujęciu Wilhelma Röpkego}

Jednym z pierwszych tekstów Röpkego, w którym odniósł się on do zagadnienia wolności, było przemówienie z lutego 1933 roku. Przedstawił w nim liberalizm jako kierunek, który nadał imię idei wolności. Istota liberalizmu polegała na wyzwoleniu jednostki z zewnętrznych wpływów autorytaryzmu, ucisku i nietolerancji. Program liberalny zakładał: tolerancję, wolność (myśli, słowa, prasy), fair play i dyskusję. Cywilizacyjna misja liberalizmu polegała na zaangażowaniu energii we wdrożenie tego programu w praktykę życia społecznego. Autentyczna kultura nie była możliwa - według Röpkego - bez „mieszczańskiej wolności”. Dla Röpkego prawdziwa, duchowa siła stworzenia pochodziła właśnie z wolności, a nie ze spokojnych opinii narzucanych przez państwo. Człowiek miał prawo wymagać zapewnienia ochrony przed samowolą i nadużyciem przemocy za każdą wypowiedź, która nie była zgodna z panującymi trendami i wyrażała indywidualizm życiowy. Oznaczało to wolę emancypacji duchowej z każdego heteronomicznego autorytaryzmu i bezwarunkowe dążenie do prawdy.

$\mathrm{Z}$ idei wolności i z umiarkowanie racjonalnych poglądów powstała idea humanizmu, który polegał na szacunku dla godności osobistej, odrzuceniu pesymizmu i przedmiotowego traktowania człowieka oraz wszelkich form ucisku. Doprowadziło to Röpkego do zasad demokracji, które najbardziej korespondowały z liberalnym poglądem na otaczający świat. To właśnie w demokracji była możliwa wolność wypowiedzi, pod warunkiem, że obie strony dyskusji posługiwały się rozsądkiem (Wesemann, 1965, s. 171-174). 
W czasie trwania II wojny światowej, Röpke przebywał w Szwajcarii i tam tworzył dalej program tzw. „trzeciej drogi” (zwanej również „konstruktywnym” lub też „rewizjonistycznym liberalizmem” albo „humanizmem ekonomicznym”, który wiódł pomiędzy kolektywizmem a XIX-wiecznym liberalizmem). Za oczywistą uważał autonomię woli ekonomicznej (dotyczyła zarówno konsumentów, jak i producentów) w wysokorozwiniętej gospodarce o skomplikowanym podziale pracy. Jednakże zapewnienie autonomii było związane z problemami. Odpowiedzią była konstytucja gospodarcza oparta na wolnym rynku i cenach, prywatnej własności środków produkcji i konkurencji. Producenci decydowali o tym co, jak i w jakich ilościach wyprodukować. Gospodarka rynkowa, w której istniał podział pracy, była kierowana przez rynek i konkurencję. To powodowało, że odpowiadała na życzenia konsumentów (Röpke, 1948, s. 42, 43, 166, 167).

Wolność gospodarcza była znaczącą formą osobistej wolności, ale także warunkiem wstępnym dla funkcjonowania społeczeństwa. Wolność również była niezbędnym warunkiem umowy społecznej. W tym społeczeństwie: a) możliwie jak największa liczba obywateli dysponowała własnością, b) osoby same dokonały wyboru miejsca zatrudnienia, c) prowadziły niezależne życie i traktowały wolność gospodarczą jako coś naturalnego, d) ton życiu nadawali najlepsi ludzie (różnych profesji: rolnicy, rzemieślnicy, właściciele małych warsztatów, małe i średnie przedsiębiorstwa handlowe oraz przemysłowe, osoby wolnych zawodów oraz urzędnicy i żołnierze), którzy dzięki własnemu życiu i pracy wpływali na losy świata. Działo się tak, gdyż stanowili oni o fizjonomii społeczeństwa. Program trzeciej drogi z wolnością i konkurencją był przeciwieństwem głównego zła, jakimi dla Röpkego były kolektywizm i monopole. Cechami tego programu były: decentralizacja w połączeniu ze wsparciem małego i średniego sektora przedsiębiorstw oraz monitorowanie rynku i zapewnienie panowania na nim zasady fair play, stawianie na nieproletariackie formy przemysłowe oraz możliwie jak największy podział własności (Röpke, 1948, s. 286-289).

Istotą „konstytucji gospodarczej” był wolny rynek i niezafałszowana konkurencja, która odbywała się przy uczciwych i równych warunkach dla wszystkich jej uczestników Wolny rynek wraz z zasadą konkurencji w wydajności w przeciwieństwie do filozofii laissez-faire miał miejsce przy udziale państwa. Tylko że państwo nie było biernym aktorem, lecz ustawodawcą, zarządzającym oraz wydającym rozstrzygnięcia prawne, prowadzącym również politykę finansową i sprawującym przy- 
wództwo duchowo-moralne, przez co troszczyło się też o wolność i konkurencję na rynku. Röpke zauważył, iż także w życiu gospodarczym obowiązywała zasada, że wolność nie była możliwa bez zachowania dyscypliny. Jeżeli naszym życzeniem było posiadanie wolnego rynku, wymagało to dla niego stworzenia odpowiedniego wsparcia w postaci ram zbudowanych z warunków, reguł i instytucji. Było miejsce także dla leseferyzmu, gdy został wdrożony w ramy prawne, które zostały określone przez tzw. policję rynkową. Wolny rynek wymagał bacznej i aktywnej polityki gospodarczej, która była świadoma swych granic interwencyjnych, poza które nie mogła wykroczyć. Tymczasem policja rynkowa miała zajmować się problemami monopoli, które przynosiły szkody społeczno-ekonomiczne (Röpke, 1948, s. 364-366).

Röpke sformułował motto, które brzmiało: wolność gospodarcza na trwałym gruncie: powszechnej własności (prywatnej), własnego domu, warsztatu i ogrodu. Powrót do naturalnego porządku (ordenaturel) jako pożądanego stanu, gdzie panował wolny ład życia gospodarczego, z dala od kolektywizmu, ale w zdecentralizowanej cywilizacji, gdzie swoją szansę na realizację posiadał ideał wolności gospodarczej (Röpke 1950, s. 137, 142, 144, 154, 157).

Obrona wolności przed zakusami ustrojów totalitarnych oraz kolektywizmu występowała również w książce Civitas Humana. Röpke argumentował, iż porządek gospodarczy (z wolnymi cenami i rynkiem) najbardziej korelował z wolnością jednostki, którą strzegły struktury państwa, a społeczeństwo zharmonizowane było $\mathrm{z}$ panowaniem prawa. Pisał te słowa $\mathrm{z}$ wiarą religijną i przekonaniem filozoficznym. Dopiero w takich warunkach człowiek mógł żyć sensownie i z godnością. Jednakże własność prywatna, zyski i konkurencja nie uzasadniały wszystkiego, ponieważ życie toczyło się także poza panowaniem zasad popytu i podaży oraz wolnych cen. Oznaczało to konieczność umieszczenia gospodarki rynkowej w wyższym porządku całościowym zbudowanym na wartościach (Röpke, 1961, s. 21-23).

Od czego zależała możliwość - zastanawiał się Röpke - pogodzenia demokracji z wolnością? Od osób, które dysponowały prawem wyborczym i w większości prezentowały pogląd o istnieniu wysokich norm i zasad życia państwowego oraz „konstytucji gospodarczej”, które były następnie uwzględniane w procesie podejmowania demokratycznych decyzji. Wolność polityczna i duchowa były niepodzielne. Reprezentowanie takich opinii było równoznaczne z odrzuceniem kolektywistycznego systemu gospodarczego opartego na zniewoleniu. Wynikało to z tego, iż kolektywizm niszczył wszystko, co miało związek z polityczną i duchową wolnością. 
Obrona wolności gospodarczej wynikała z kilku powodów: wolność miała związek z moralnością, człowieczeństwem i wartościami nieprzemijającymi charakterystycznymi dla kultury zachodniej. Dlatego też - zdaniem Röpkego - ekonomiści powinni byli aktywnie włączyć się do obrony wolności, osobowości i państwa prawa. Świat zachodni w przeciwieństwie do komunistycznego pragnął obronić swój ideał kultury i państwa. Pluralistyczny system zachodni kontra monolityczny system komunizmu - w tej rywalizacji główną stawką był świat wolności. Samodzielnymi (autonomicznymi) obszarami pluralistycznego społeczeństwa były wolność i przynależąca do niej gospodarka (Röpke, 1961, s. 107, 162, 203).

\section{Podsumowanie}

Dla obu ordoliberalnych twórców wolność posiadała ważne znaczenie. Odzwierciedlało to m.in. umieszczenie przez Waltera Euckena wolności wśród siedmiu zasad konstytuujących porządek gospodarczy. Rynkowy ład gospodarczy wymagał istnienia wolności. Właśnie wolność i porządek stanowiły jedność. Oznaczało to w praktyce zapewnienie wolności obywatelskiej oraz wolność prowadzenia działalności gospodarczej dla przedsiębiorców. Z kolei dla Wilhelma Röpkego wolność gospodarcza (na gruncie własności prywatnej) była formą wolności osobistej. Ponadto wolność była warunkiem umowy społecznej i podstawową wartością dla cywilizacji Europy Zachodniej. Polityczna i duchowa wolność była nierozłączną parą, podobnie jak wolny rynek i konkurencja.

\section{Literatura}

Eucken, W. (1950). Die Grundlagen der Nationalökonomie. Berlin, Göttingen, Heidelberg: Springer Verlag.

Eucken, W. (1990). Grundsätze der Wirtschaftspolitik. Tübingen: J.C.B. Mohr (Paul Siebeck). Eucken, W. (2005). Nationalökonomie wozu? Stuttgart: Klett-Cotta.

Eucken, W. (2001). Wirtschaftsmacht und Wirtschaftsordnung. Londoner Vorträge zur Wirtschaftspolitik und zwei Beiträge zur Antimonopolpolitik. Münster, Hamburg, London: Lit Verlag.

Grabowski, A. (2013). Przedsiębiorstwa sportowe w gospodarce rynkowej. Na przykladzie FC Bayern Monachium SA. Warszawa: Wydawnictwo WNT. 
Hennecke, H.J. (2009). Wilhelm Röpke. Marktwirtschaft ist nicht genug. Gesammelte Aufsätze. Waltrop, Leipzig: Manuscriptum Verlagsbuchhandlung.

Röpke, W. (1949). Civitas Humana. Grundfragen der Gesellschafts-und Wirtschaftsreform. Erlenbach-Zürich: Eugen Rentsch Verlag.

Röpke, W. (1948). Die Gesellschaftskrisis der Gegenwart. Erlenbach-Zürich: Eugen Rentsch Verlag.

Röpke, W. (1994). Die Lehre von der Wirtschaft. Bern, Stuttgart, Wien: Paul Haupt Verlag. Röpke, W.(1961). Jenseits von Angebot und Nachfrage. Erlenbach-Zürich, Stuttgart: Eugen Rentsch Verlag.

Röpke, W. (1950). Mass und Mitte. Erlenbach-Zürich: Eugen Rentsch Verlag.

Röpke, W. (1962). Wirrnis und Wahrheit. Ausgewählte Aufsätze. Erlenbach-Zürich, Stuttgart: Eugen Rentsch Verlag.

Wesemann, H.O. (1965). Wilhelm Röpke. Fronten der Freiheit. Wirtschaft - Internationale Ordnung - Politik. Stuttgart: Seewald Verlag.

\title{
CATEGORY OF FREEDOM IN ORDOLIBERALISM ON THE EXAMPLE OF VIEWS OF WALTER EUCKEN AND WILHELM RÖPKE
}

\begin{abstract}
One of the basic economic categories for ordoliberalism was the freedom. It was due to assumptions of the ordoliberalism doctrine. At the foundation of the legal and institutional order first economic order was made, from which a market economy emerged. In this order prevailed: freedom, competition and private ownership. For the leading representatives of ordoliberalism (Walter Eucken and Wilhelm Röpke), the freedom was one of the fundamental principle of constituting a market order and attribute of peoples. Every citizen had guaranteed the freedom of establishment and the use of private ownership of the means of production.
\end{abstract}

Keywords: market economy, competition, ordoliberalism, freedom

Kody JEL: B29, B30, B31, B59 